Sains Malaysiana 47(7)(2018): 1617-1623

http://dx.doi.org/10.17576/jsm-2018-4707-33

\title{
Mixed Convection Flow of Viscoelastic Nanofluid Past a Horizontal Circular Cylinder with Viscous Dissipation
}

(Aliran Olakan Campuran Bendalir Nano Likat melalui Silinder Bulat Mengufuk dengan Pelepasan Likat)

\author{
RAHIMAH MAHAT, NORAIHAN AFIQAH RAWI, AbDUl RAHMAN MOHD KASIM \& SHARIDAN SHAFIE*
}

\begin{abstract}
The purpose of this study was to examine the effect of viscous dissipation on mixed convection flow of viscoelastic nanofluid past a horizontal circular cylinder. Carboxymethyl cellulose solution (CMC) is chosen as the base fluid and copper as a nanoparticle with the Prandtl number $\mathrm{Pr}=6.2$. The transformed boundary layer equations for momentum and temperature subject to the appropriate boundary conditions are solved numerically by using Keller-box method. The influenced of the dimensionless parameters such as Eckert number, mixed convection parameter, nanoparticles volume fraction and viscoelastic parameter on the flow and heat transfer characteristics is analyzed in detail and presented graphically. The results come out with the velocity profiles are increased while the temperature profiles are decreased by increasing the values of nanoparticles volume fraction and viscoelastic parameter, respectively. The graph shows that, increasing Eckert number the skin friction is also increases. The values of skin friction are increased by increasing mixed convection parameter, but the values of Nusselt number produce an opposite behavior. The present study has many applications especially in heat exchangers technology and oceanography. Therefore, in future, it is hoping to study the viscoelastic nanofluid flow past a different geometric such as sphere and cylindrical cone.
\end{abstract}

Keywords: Horizontal circular cylinder; nanofluid; viscoelastic; viscous dissipation

ABSTRAK

Tujuan kajian ini adalah untuk mengkaji kesan pelesapan likat pada aliran olakan campuran bendalir-nano likat kenyal melepasi sebuah silinder membulat yang mengufuk. Larutan selulosa karboksimetil (CMC) dipilih sebagai bendalir dasar dan tembaga sebagai nano zarah dengan nombor Prandtl Pr =6.2. Persamaan lapisan sempadan yang diubah untuk momentum dan suhu tertakluk kepada syarat sempadan yang bersesuaian diselesaikan secara berangka dengan menggunakan Kotak-Keller. Kesan pemboleh ubah tanpa matra seperti nombor Eckert, parameter olakan campuran, pecahan isi padu nano zarah dan parameter likat kenyal ke atas aliran dan sifat pemindahan haba dianalisis secara terperinci dan dibincangkan secara grafik. Keputusan menunjukkan bahawa profil halaju meningkat manakala profil suhu menurun masing-masing dengan peningkatan nilai pecahan isi padu nano zarah dan parameter likat kenyal. Graf menunjukkan bahawa dengan peningkatan nombor Eckert, geseran kulit juga meningkat. Nilai geseran kulit meningkat dengan peningkatan parameter olakan campuran, tetapi nilai nombor Nusselt menghasilkan tingkah laku yang bertentangan. Kajian semasa ini mempunyai banyak aplikasi terutamanya dalam teknologi penukaran haba dan oseanografi. Oleh itu, pada masa akan datang, diharapkan dapat mengkaji aliran bendalir-nano likat kenyal melepasi geometri yang berbeza seperti sfera dan kon bersilinder.

Kata kunci: Bendalir-nano; likat kenyal; pelesapan likat; silinder bulat mengufuk

\section{INTRODUCTION}

The concept of nanofluid was first manifested by series of research at Argonne National Laboratory and Choi and Eastman (1995) was the first to call the fluids with particles of nanometer dimension suspended in them as 'Nano-fluids' which has gained popularity. Nanoparticles used in nanofluid can be classified by materials. The nanoparticles are consisting of nano sized metals, oxides and carbon nanotubes. Recently, study of nanofluid has become most popular among researchers' due to its various applications in many industries, engineering and medical sciences. Basically, this kind of fluid have extremely high thermal conductivities compared to the conventional liquids, then nanofluid has been proposed as a route for surpassing the performance of heat transfer liquids. Many researchers had involved in the study of boundary layer flow problem in nanofluid such as Ahmad and Pop (2010)Al2O3 (aluminium, Khan and Pop (2010), Nield and Kuznetsov (2009), Noghrehabadi et al. (2012), Rashad et al. (2013), Qasim et al. (2013) and Zaib et al. (2015). Recently, Hayat et al. (2016) investigated mixed convection flow of viscoelastic nanofluid past a cylinder with variable thermal conductivity and heat source/sink. In reality, most fluids are non-Newtonian. Non-Newtonian 
fluid means that their viscosity is dependent on shear rate (thickening) or the deformation history. Nowadays, the non-Newtonian nanofluid has received much considerable interest and concern by the researchers' due to the potential of nanofluid applications in many types of industry. Bouchoucha and Bessaih (2015) and Mabood et al. (2016) had studied some interesting problems involving the non-Newtonian nanofluid with various conditions and geometries.

In all investigations as mention before, the viscous dissipation effect is neglected. The viscous dissipation is appreciable when the induced kinetic energy becomes significant compared to the amount of heat transferred according to Gebhart (1962), the first researcher who studied about viscous dissipation in free convection flow. Then, the viscous dissipation effect on unsteady free convective flow over a vertical porous plate was then investigated by Soundalgekar (1972). Recently, Dalir (2014) considered the numerical study of entropy generation for forced convection flow and heat transfer of Jeffrey fluid over a stretching sheet. Very recently, Zokri et al. (2017a, 2017b), considered magnetohydrodynamic (MHD) Jeffrey nanofluid past a stretching sheet with viscous dissipation effect and numerical solution on mixed convection boundary layer flow past a horizontal circular cylinder in Jeffrey fluid with constant heat flux, respectively. Motivated from the literature studies, in this present study, the steady two-dimensional mixed convection boundary layer flow past a horizontal circular cylinder in viscoelastic nanofluid with viscous dissipation is investigated. Considering Tiwari and Das (2007), the influence of mixed convection parameter, viscoelastic parameter, viscous dissipation and nanoparticles volume fraction on the boundary layer flow of viscoelastic nanofluid are analysed.

\section{MATERIALS AND METHODS}

In this paper, the mixed convection boundary layer flow past a horizontal circular cylinder of radius $a$ placed in a viscoelastic nanofluid with viscous dissipation is studied. Figure 1 illustrates the geometry of the problem and the corresponding coordinates system.

It is assumed that the constant temperature of the surface of the cylinder is $T_{w}$ and that of the ambient fluid is $T_{\infty}$, where $T_{w}>T_{\infty}$ corresponds to a heated cylinder (assisting flow) and $T_{w}<T_{\infty}$ corresponds to a cooled cylinder (opposing flow), respectively. Furthermore, following Merkin (1977), the velocity of the freestream is assumed as $(1 / 2) U_{\infty}$. Under these assumptions along with the Boussinesq approximation, the boundary layer equations can be written as Merkin (1977), Nayak (2016) and Nazar et al. (2002);

$$
\frac{\partial \bar{u}}{\partial \bar{x}}+\frac{\partial \bar{v}}{\partial \bar{y}}=0
$$

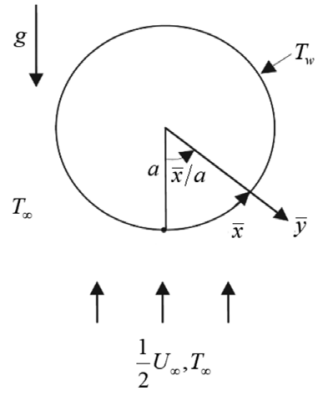

FIGURE 1. Physical model and coordinates system

$$
\begin{aligned}
& \rho_{n f}\left(\bar{u} \frac{\partial \bar{u}}{\partial \bar{x}}+\bar{v} \frac{\partial \bar{u}}{\partial \bar{y}}\right)=\rho_{n f} \bar{u}_{e} \frac{\partial \bar{u} e}{\partial \bar{x}}+\mu_{n f} \frac{\partial^{2} \bar{u}}{\partial \bar{y}^{2}} \\
& +k_{0}\left[\frac{\partial}{\partial \bar{x}}\left(\bar{u} \frac{\partial^{2} \bar{u}}{\partial \bar{y}^{2}}\right)+\bar{v} \frac{\partial^{3} \bar{u}}{\partial \bar{y}^{3}}-\frac{\partial \bar{u}}{\partial \bar{y}} \frac{\partial^{2} \bar{u}}{\partial \bar{x} \partial \bar{y}}\right] \\
& +g(\rho \beta)_{n f}\left(T-T_{\infty}\right) \sin \left(\frac{\bar{x}}{a}\right), \\
& \left(\rho C_{p}\right)_{n f}\left[\bar{u} \frac{\partial T}{\partial \bar{x}}+\bar{v} \frac{\partial T}{\partial \bar{y}}\right]=k_{n f} \frac{\partial^{2} T}{\partial \bar{y}^{2}}+v\left(\frac{\partial \bar{u}}{\partial \bar{y}}\right)^{2}+ \\
& k_{0}\left(\bar{u} \frac{\partial \bar{u}}{\partial \bar{y}} \frac{\partial^{2} \bar{u}}{\partial \bar{x}} \partial \bar{y} \bar{v} \frac{\partial \bar{u}}{\partial \bar{y}} \frac{\partial^{2} \bar{u}}{\partial \bar{y}^{2}}\right),
\end{aligned}
$$

subjected to the boundary conditions:

$$
\begin{aligned}
& \bar{u}=0, \quad \bar{v}=0, T=T_{w} \text { at } \bar{y}=0, \bar{x} \geq 0, \\
& \bar{u}=\bar{u}_{\mathrm{e}}(\bar{x}), \frac{\partial \bar{u}}{\partial \bar{y}}=0, T=T_{\infty} \text { as } \bar{y} \rightarrow \infty, \bar{x} \geq 0,
\end{aligned}
$$

where $\bar{x}$ and $\bar{y}$ are the Cartesian coordinates along the surface of the cylinder. The value is starting from the lower stagnation point of the cylinder. While $\bar{y}$ is the coordinate measured normal to the surface of the cylinder; $\bar{u}$ and $\bar{v}$ are the velocity components; $\bar{u}_{e}(\bar{x})$ is the velocity outside the boundary layer; $\mu$ is the dynamic viscosity; $g$ is the gravity acceleration; $T$ is the temperature of selected fluid; $k_{0}>0$ is the constant of the viscoelastic material (Walter's Liquid-B model); $\rho_{n f}$ and $\mu_{n f}$ are the density and dynamic viscosity of nanofluid; $(\beta)_{n f}$ is the thermal expansion of nanofluid; $k_{n f}$ is the effective thermal conductivity of the nanofluid; and $\left(\rho C_{p}\right)_{n f}$ is the heat capacitance of nanofluid. These nanofluid constants are defined by,

$$
\begin{aligned}
& \left(\rho C_{p}\right)_{n f}=(1-\phi)\left(\rho C_{p}\right)_{f}+\phi\left(\rho C_{p}\right)_{s}, \\
& (\rho \beta)_{n f}=(1-\phi)(\rho \beta)_{f}+\phi(\rho \beta)_{s}, \\
& \mu_{n f}=\frac{\mu_{f}}{(1-\phi)^{2.5}}, \quad \rho_{n f}=(1-\phi) \rho_{f}+\phi \rho_{s},
\end{aligned}
$$


TABLE 1. Thermophysical properties of nanoparticles and base fluid

\begin{tabular}{lcccc}
\hline Physical properties & $\rho\left(\mathrm{kg} \mathrm{m}^{-3}\right)$ & $C_{p}\left(\mathrm{~J} \mathrm{~kg}^{-1} \mathrm{~K}^{-1}\right)$ & $k\left(\mathrm{Wm}^{-1} \mathrm{~K}^{-1}\right)$ & $\beta \times 10^{5}\left(K^{-1}\right)$ \\
\hline Base Fluid $(\mathrm{CMC})$ & 997.1 & 4179 & 0.613 & 21 \\
Nanoparticle $(\mathrm{Cu})$ & 8933 & 385 & 401 & 1.67 \\
\hline
\end{tabular}

$$
k_{n f}=k_{f} \frac{\left(k_{s}+2 k_{f}\right)-2 \phi\left(k_{f}-k_{s}\right)}{\left(k_{s}+2 k_{f}\right)+\phi\left(k_{f}-k_{s}\right)}
$$

where $\phi$ is the nanoparticles volume fraction of the nanofluid. The thermophysical properties of nanoparticle and base fluid is given in Table 1 (Lin et al. 2014).

By introducing the following non-dimensional variables;

$$
\begin{aligned}
& x=\bar{x} / a, \quad y=\operatorname{Re}^{1 / 2}(\bar{y} / a), \quad u=\bar{u} / U_{\infty}, \\
& v=\operatorname{Re}^{1 / 2}\left(\bar{v} / U_{\infty}\right), \quad u_{e}(x)=\bar{u}_{e}(\bar{x}) / U_{\infty}, \\
& \theta=\left(T-T_{\infty}\right) /\left(T_{w}-T_{\infty}\right)
\end{aligned}
$$

where $\operatorname{Re}=U_{\infty} a / v$ is the Reynolds number; and $v$ is kinematic viscosity and substitute (6) into (1) to (3), the dimensionless equations are obtained as,

$$
\frac{\partial u}{\partial x}+\frac{\partial v}{\partial y}=0
$$

$$
\begin{gathered}
{\left[(1-\phi)+\phi \frac{\rho_{s}}{\rho_{f}}\right]\left[u \frac{\partial u}{\partial x}+v \frac{\partial u}{\partial y}\right]=\left[(1-\phi)+\phi \frac{\rho_{s}}{\rho_{f}}\right]} \\
u_{e} \frac{\partial u_{e}}{\partial x}+\frac{1}{(1+\phi)^{2.5}} \frac{\partial^{2} u}{\partial y^{2}} \\
+K\left[\frac{\partial}{\partial x}\left(u \frac{\partial^{2} u}{\partial y^{2}}\right)+v \frac{\partial^{3} u}{\partial y^{3}}-\frac{\partial u}{\partial y} \frac{\partial^{2} u}{\partial x \partial y}\right] \\
+\left[(1-\phi)+\phi \frac{(\rho \beta)_{s}}{(\rho \beta)_{f}}\right] \lambda \theta \sin (x), \\
{\left[(1-\phi)+\phi \frac{\left.\left(\rho C_{p}\right)_{s}\right]}{\left.\left(\rho C_{p}\right)_{f}\right]}\left[u \frac{\partial \theta}{\partial x}+v \frac{\partial \theta}{\partial y}\right]=\frac{\left(k_{s}+2 k_{f}\right)-2 \phi\left(k_{f}-k_{s}\right)}{\left(k_{s}+2 k_{f}\right)+\phi\left(k_{f}-k_{s}\right)} \frac{1}{\operatorname{Pr}} \frac{\partial^{2} \theta}{\partial y^{2}}\right.} \\
+E c\left[\left(\frac{\partial u}{\partial y}\right)^{2}+K\left(u \frac{\partial u}{\partial y} \frac{\partial^{2} u}{\partial x \partial y}+v \frac{\partial u}{\partial y} \frac{\partial^{2} u}{\partial y^{2}}\right)\right],
\end{gathered}
$$

with the new boundary conditions,

$$
\begin{aligned}
& u=0, \quad v=0, \quad \theta=1 \quad \text { at } y=0, x \geq 0, \\
& u=u_{e}(x), \frac{\partial u}{\partial y}=0, \theta=0 \text { as } y \rightarrow \infty, x \geq 0 .
\end{aligned}
$$

where $E c=\frac{U_{\infty}^{2}}{\left(C_{p}\right)_{n f}\left(T_{w}-T_{\infty}\right)}$ is an Eckert number, $\operatorname{Pr}=\frac{v}{\alpha}$ is the Prandtl number, $K=\frac{k_{0} U_{\infty}}{a \rho v}$ is the dimensionless viscoelastic parameter, $\phi$ is the nanoparticles volume fraction of the fluid and $\lambda=\frac{G r}{\mathrm{Re}^{2}}$ is the constant mixed convection parameter, where $G r=g \beta\left(T_{w}-T_{\infty}\right) a^{3} / v^{2}$ is known as a Grashof number. $\lambda>0$ is correlate to an auxiliary flow while $\lambda<0$ is correlate to the opposing flow, whereas $\lambda=0$ is correlate to the forced convection flow, respectively. In this problem, when $K=0$ is referred to the case of viscous (Newtonian) fluids.

In order to solve (7) to (9), functions

$$
\psi=x F(x, y), \quad \theta=\theta(x, y),
$$

are introduced where $\psi$ is the stream function defined as

$$
u=\frac{\partial \psi}{\partial y}, \quad v=-\frac{\partial \psi}{\partial x} .
$$

By using (12) and (13) into (8) and (9), we obtained

$$
\begin{aligned}
{\left[(1-\phi)+\phi \frac{\rho_{s}}{\rho_{f}}\right]\left[\left(\frac{\partial F}{\partial y}\right)^{2}+x \frac{\partial F}{\partial y}\left(\frac{\partial^{2} F}{\partial x \partial y}\right)-x \frac{\partial F}{\partial x} \frac{\partial^{2} F}{\partial y^{2}}-F \frac{\partial^{2} F}{\partial y^{2}}\right] } \\
=\left[(1-\phi)+\phi \frac{\rho_{s}}{\rho_{f}}\right] \frac{\sin x \cos x}{x}+\frac{1}{(1+\phi)^{2.5}} \frac{\partial^{3} F}{\partial y^{3}} \\
+\left[(1-\phi)+\phi \frac{(\rho \beta)_{s}}{(\rho \beta)_{f}}\right] \lambda \theta \frac{\sin x}{x}+K\left[2 \frac{\partial F}{\partial y} \frac{\partial^{3} F}{\partial y^{3}}-F \frac{\partial^{4} F}{\partial y^{4}}-\right. \\
\left.\left(\frac{\partial^{2} F}{\partial y^{2}}\right)^{2}+x\left(\frac{\partial^{2} F}{\partial x \partial y} \frac{\partial^{3} F}{\partial y^{3}}-\frac{\partial F}{\partial x} \frac{\partial^{4} F}{\partial y^{4}}+\frac{\partial F}{\partial y} \frac{\partial^{4} F}{\partial x \partial y^{3}}-\frac{\partial^{2} F}{\partial y^{2}} \frac{\partial^{3} F}{\partial x \partial y^{2}}\right)\right],
\end{aligned}
$$




$$
\begin{aligned}
& \frac{\left(k_{s}+2 k_{f}\right)-2 \phi\left(k_{f}-k_{s}\right)}{\left(k_{s}+2 k_{f}\right)+\phi\left(k_{f}-k_{s}\right)} \frac{1}{\operatorname{Pr}} \frac{\partial^{2} \theta}{\partial y^{2}}+ \\
& {\left[(1-\phi)+\phi \frac{\left(\rho C_{p}\right)_{s}}{\left(\rho C_{p}\right)_{f}}\right] F \frac{\partial \theta}{\partial y}} \\
& =x\left[\begin{array}{l}
(1-\phi)+\phi \frac{\left(\rho C_{p}\right)_{s}}{\left(\rho C_{p}\right)_{f}}\left(\frac{\partial F}{\partial y} \frac{\partial \theta}{\partial x}-\frac{\partial F}{\partial x} \frac{\partial \theta}{\partial y}\right) \\
-E c x\left[\left(\frac{\partial^{2} F}{\partial y^{2}}\right)^{2}+K\left(x \frac{\partial F}{\partial y} \frac{\partial^{2} F}{\partial y^{2}} \frac{\partial^{3} F}{\partial x \partial y^{2}}\right.\right.
\end{array}\right. \\
& C_{f}=\operatorname{Re}^{1 / 2} \frac{\tau_{w}}{\rho U_{\infty}^{2}}, \quad N u_{x}=\operatorname{Re}^{-1 / 2} \frac{a q_{w}}{k\left(T_{w}-T_{\infty}\right)}, \\
& \tau_{w}=\mu\left(\frac{\partial \bar{u}}{\partial \bar{y}}\right)_{\bar{y}=0}+k_{0}\left(\bar{u} \frac{\partial^{2} \bar{u}}{\partial \bar{x} \partial \bar{y}}+\bar{v} \frac{\partial^{2} \bar{u}}{\partial \bar{y}^{2}}+2 \frac{\partial \bar{u}}{\partial \bar{x}} \frac{\partial \bar{u}}{\partial \bar{y}}\right)_{\bar{y}=0}, \\
& q_{w}=-k\left(\frac{\partial T}{\partial \bar{y}}\right)_{y=0} .
\end{aligned}
$$

By substituting (6) and (18) into (17), we obtained

$$
C_{f} \operatorname{Re}_{x}^{1 / 2}=x\left(\frac{\partial^{2} F}{\partial y^{2}}\right)_{\bar{y}=0}, N u_{x} \operatorname{Re}_{x}^{-1 / 2}=-\left(\frac{\partial \theta}{\partial y}\right)_{\bar{y}=0} .
$$

which are subject to the following boundary conditions,

$$
\begin{aligned}
& F=0, \frac{\partial F}{\partial y}=0, \theta=1, \quad \text { at } y=0, x \geq 0, \\
& \frac{\partial F}{\partial y}=\frac{\sin x}{x}, \frac{\partial^{2} F}{\partial y^{2}}=0, \theta=0, \text { as } y \rightarrow \infty, x \geq 0 .
\end{aligned}
$$

At the lower stagnation point of the cylinder, $x \approx 0,(14)$ and (15) are reduce to the following ordinary differential equations,

$$
\begin{array}{r}
\frac{1}{(1+\phi)^{2.5} f^{\prime \prime \prime}-\left[(1-\phi)+\phi \frac{\rho_{s}}{\rho_{f}}\right]\left[f^{\prime 2}-f f^{\prime \prime}\right]+K\left(2 f f^{\prime \prime \prime}-f f^{i v}-f^{\prime 2}\right)} \\
+\left[(1-\phi)+\phi \frac{(\rho \beta)_{s}}{(\rho \beta)_{f}}\right] \lambda \theta=0
\end{array}
$$

$$
\frac{\left(k_{s}+2 k_{f}\right)-2 \phi\left(k_{f}-k_{s}\right)}{\left(k_{s}+2 k_{f}\right)+\phi\left(k_{f}-k_{s}\right)} \frac{1}{\operatorname{Pr}} \theta^{\prime}+\left[(1-\phi)+\phi \frac{\left(\rho C_{p}\right)_{s}}{\left(\rho C_{p}\right)_{f}}\right] f \theta^{\prime}=0,
$$

with the boundary conditions

$$
\begin{array}{ll}
f(0)=0, & f^{\prime}(0)=0, \quad \theta^{\prime}(0)=1 \\
f^{\prime}(\infty)=1, & f^{\prime \prime}(\infty)=0, \quad \theta(\infty)=0,
\end{array}
$$

where primes denote the differentiation with respect to $y$.

The physical quantities interest of this problem is the Nusselt number $N u_{x}$ and the skin friction coefficient $C_{f}$, that are defined as,

\section{RESULTS AND DISCUSSION}

The systems of (14) - (16) and (17) - (19) were solved numerically using the finite different scheme method known as Keller-box method. Four parameters are considered, namely the Eckert number $E c$, mixed convection parameter $\lambda$, nanoparticles volume fraction $\phi$ as well as viscoelastic parameter $K$. Figures 2 and 3 show the comparison values of skin friction $C_{f} \operatorname{Re}_{x}^{1 / 2}$ and Nusselt number $N u_{x} \operatorname{Re}_{x}^{-1 / 2}$ with previous results by Merkin (1977) and Nazar et al. (2002) when the viscous dissipation effect and viscoelastic is neglected, which is $E c=0$ and $K=0$, respectively. It is worth to mention that the Kellerbox method is efficiently and very accurate to solve this problem since the results is in a good agreement.

Figure 4 displays the temperature profiles for different values of $\lambda$. From the graph, it is found that thermal boundary layer thickness decreases when $\lambda$ increases. This is due to decrease in thermal diffusivity which reduced the energy ability and the thermal boundary layer thickness.

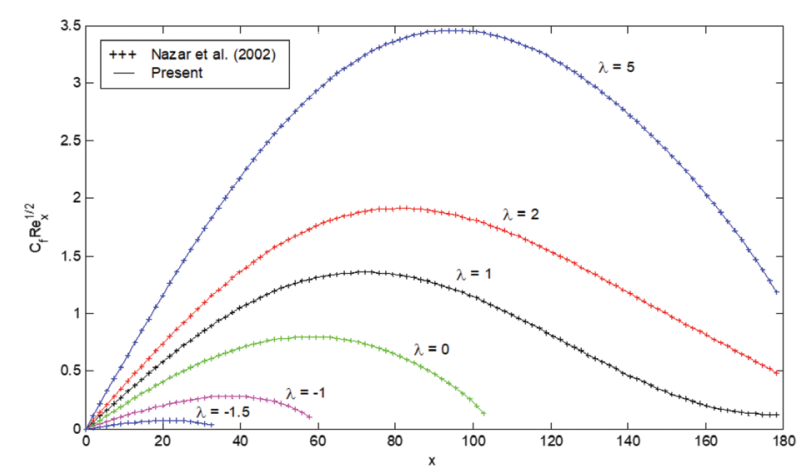

FIGURE 2. Comparison of the skin friction for $K=0$

(Newtonian fluid), $\operatorname{Pr}=1, \phi=0, E c=0$ and different values of $\lambda$ 


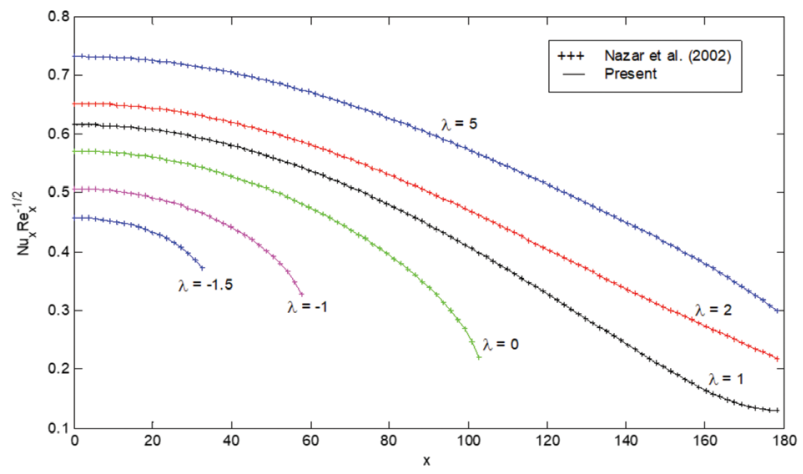

FIGURE 3. Comparison of the Nusselt number for $K=0$ (Newtonian fluid), $\operatorname{Pr}=1, \phi=0, E c=0$ and different values of $\lambda$

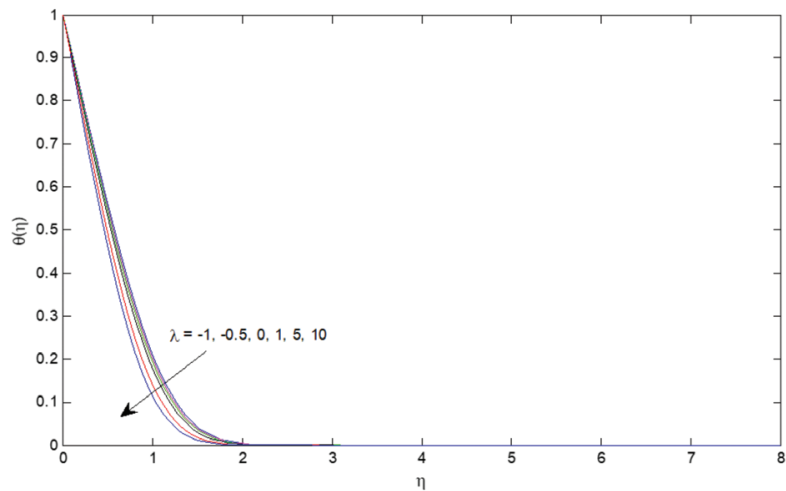

FIGURE 4 . Temperature profiles for different values of $\lambda$ with $E c=0.1, K=1$ and $\phi=0.1$

Figures 5 and 6 show $C_{f} \operatorname{Re}_{x}^{1 / 2}$ and $N u_{x} \operatorname{Re}_{x}^{-1 / 2}$ for $K=$ $1, \lambda=1$ and various values of $E c$ with the presence of nanoparticles volume fraction, $\phi=0.1$. In Figure 5 , it is found that $C_{f} \operatorname{Re}_{x}^{1 / 2}$ is unique for all values of $E c$. The graph shows that the influenced of $E c$ on $C_{f} \operatorname{Re}_{x}^{1 / 2}$ as $E c$ increases, the graph of $C_{f} \operatorname{Re}_{x}^{1 / 2}$ is also increases. Figure 6 shows that the graph of $N u_{x} \operatorname{Re}_{x}^{-1 / 2}$ decreases as the value of $E c$ increases. Both results of $C_{f} \mathrm{Re}_{x}^{1 / 2}$ and $N u_{x} \mathrm{Re}_{x}^{-1 / 2}$ show the same behavior as reported by Mohamed et al. (2016) for viscous fluid.

Finally, Figures 7 - 10 illustrate the velocity and temperature profiles for the various values of $\phi$ and $\lambda$, respectively. These figures show the influenced of $\phi$ and $\lambda$ on the fluid velocity and temperature profiles. The results show that by increasing the value of $\phi$, velocity profiles increase but temperature profiles decrease as shown in Figures 7 and 8. Meanwhile, Figures 9 and 10 show the effect of viscoelastic parameter $K$ on the fluid velocity and temperature profiles. The velocity profiles decrease when $K$ is increased and that the values of these profiles are lower for a viscoelastic fluid compared to a Newtonian fluid ( $K=$ $0)$. Therefore, the thickness of the velocity boundary layer for a viscoelastic fluid is higher compared to a Newtonian fluid.

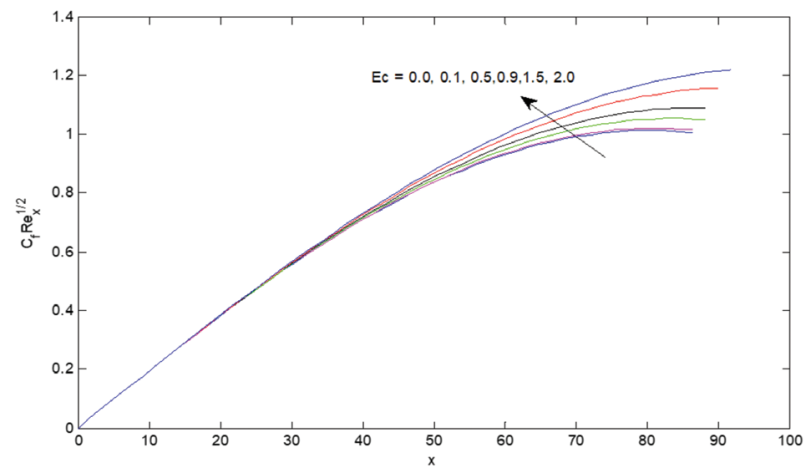

FIGURE 5. Skin friction coefficient for different values of $E c$ with $\lambda=1, K=1$ and $\phi=0.1$

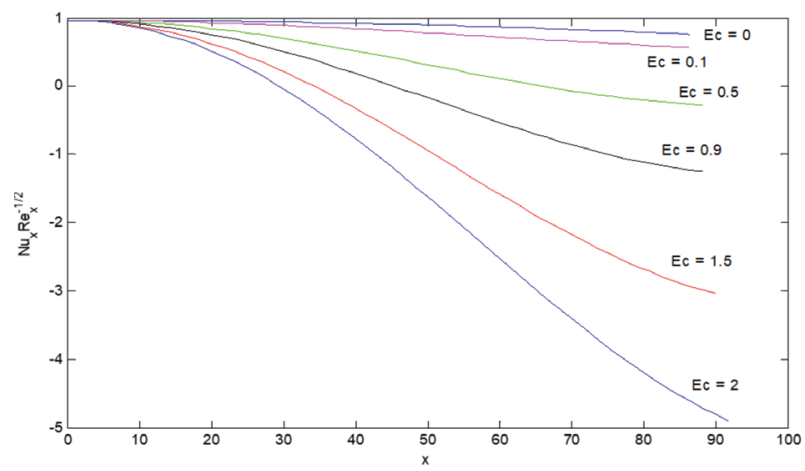

FIGURE 6. Nusselt number for different values of $E c$ with $\lambda=1$, $K=1$ and $\phi=0.1$

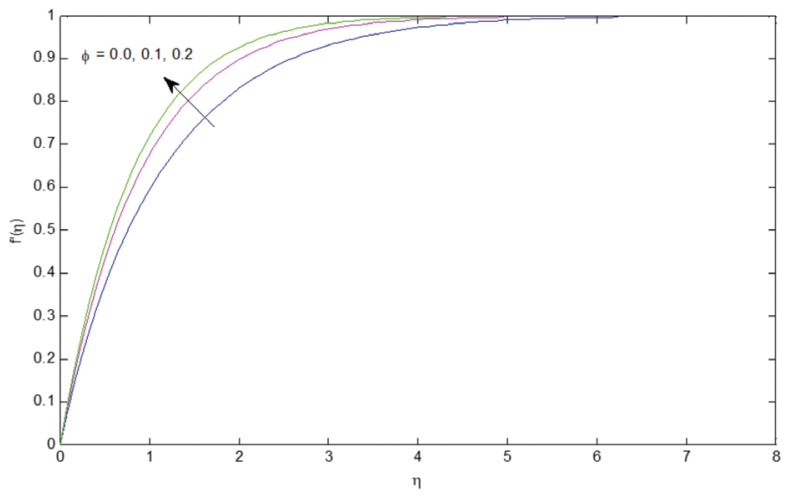

FIGURE 7. Velocity profiles for different values of nanoparticles volume fraction $\phi$ with $\lambda=1, K=1$ and $E c=0.1$

\section{CONCLUSION}

In this paper, the mathematical modelling of mixed convection boundary layer flow of viscoelastic nanofluid past a horizontal circular cylinder with viscous dissipation has been solved numerically using Keller-Box method. It is shown that the viscoelastic parameter $K$, Eckert number $E c$, nanoparticles volume fraction $\phi$ and the mixed convection parameter $\lambda$ affected the values of the Nusselt number and skin friction coefficient as well as the velocity and temperature profiles. 


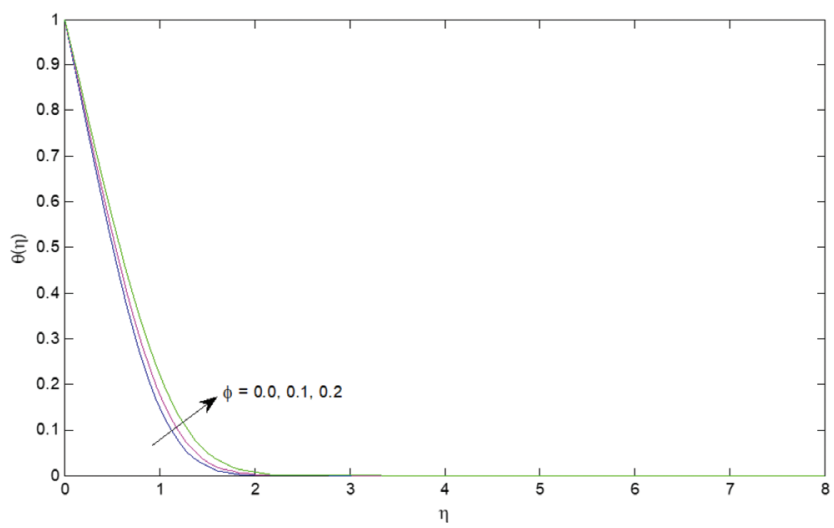

FIGURE 8 . Temperature profiles for different values of nanoparticles volume fraction $\phi$ with $\lambda=1, K=1$ and $E c=0.1$

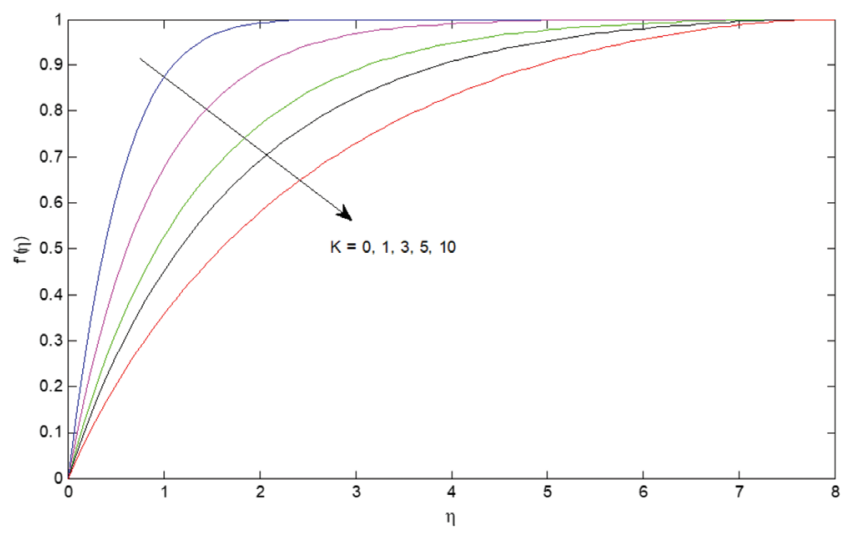

FIGURE 9. Velocity profiles for different values of $K$ when $\lambda=1$, $E c=0.1$ and $\phi=0.1$

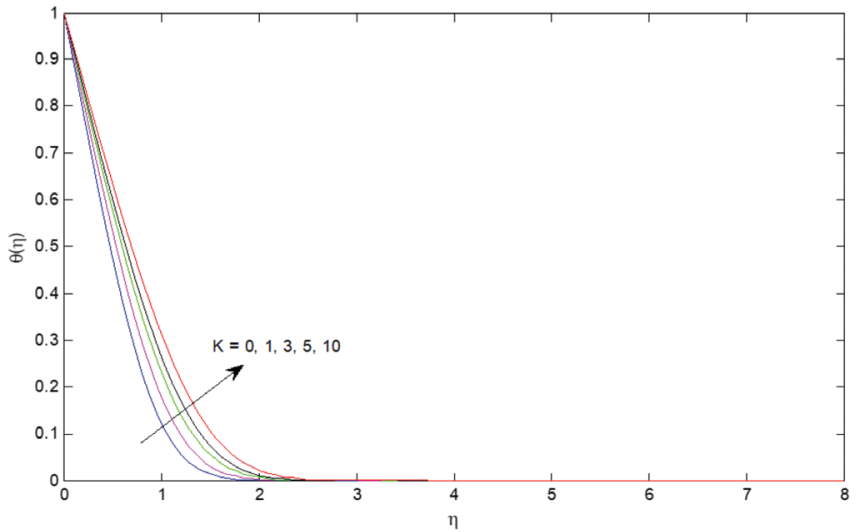

FIGURE 10. Temperature profiles for different values of $K$ when $\lambda=1, E c=0.1$ and $\phi=0.1$

As a conclusion, by increasing $\lambda$ thermal boundary layer thickness reduces. This is due to decrease in thermal diffusivity which reduced the energy ability and the thermal boundary layer thickness. The effect of Eckert number $E c$ on the skin friction and Nusselt number show the opposite behaviour for each others.

\section{ACKNOWLEDGEMENTS}

The authors would like to acknowledge the Center for Research and Innovation, UniKL, Research Management Centre, UTM and Ministry of Higher Education (MOHE), Malaysia for the financial support through vote numbers STRG 15095, 13H74 and 4F713 for this research. 


\section{REFERENCES}

Ahmad, S. \& Pop, I. 2010. Mixed convection boundary layer flow from a vertical flat plate embedded in a porous medium filled with nanofluids. International Communications in Heat and Mass Transfer 37(8): 987-991.

Bouchoucha, A.E.M. \& Bessaih, R. 2015. Natural convection in a square cavity filled with nanofluids. Fluid Dynamics and Materials Processing 11(3): 279-300.

Choi, S.U.S. \& Eastman, J.A. 1995. Enhancing Thermal Conductivity of Fluids with Nanoparticles. doi: https://www. osti.gov/servlets/purl/196525.

Dalir, N. 2014. Numerical study of entropy generation for forced convection flow and heat transfer of a jeffrey fluid over a stretching sheet. Alexandria Engineering Journal 53(4): 769-778.

Gebhart, B. 1962. Effects of viscous dissipation in natural convection. Journal of Fluid Mechanics 14(2): 225-232.

Hayat, T., Waqas, M., Shehzad, S.A. \& Alsaedi, A. 2016. Mixed convection flow of viscoelastic nanofluid by a cylinder with variable thermal conductivity and heat source/sink. International Journal of Numerical Methods for Heat \& Fluid Flow 26(1): 214-234.

Khan, W.A. \& Pop, I. 2010. Boundary-layer flow of a nanofluid past a stretching sheet. International Journal of Heat and Mass Transfer 53(11-12): 2477-2483.

Lin, Y., Zheng, L. \& Zhang, X. 2014. Radiation effects on Marangoni convection flow and heat transfer in pseudoplastic non-Newtonian nanofluids with variable thermal conductivity. International Journal of Heat and Mass Transfer 77: 708-716.

Mabood, F., Khan, W.A. \& Yovanovich, M.M. 2016. Forced convection of nanofluid flow across horizontal circular cylinder with convective boundary condition. Journal of Molecular Liquids 222: 172-180.

Merkin, J.H. 1977. Mixed convection from a horizontal circular cylinder. International Journal of Heat and Mass Transfer 20(1): 73-77.

Mohamed, M.K.A., Salleh, M.Z., Md. Noar, N.A.Z. \& Ishak, A. 2016. The viscous dissipation effects on the mixed convection boundary layer flow. Jurnal Teknologi 4: 73-79.

Nayak, M.K. 2016. Chemical reaction effect on mhd viscoelastic fluid flow over a vertical stretching sheet through porous medium. Ain Shams Engineering Journal 51(8): 1699-1711.

Nazar, R., Amin, N. \& Pop, I. 2002. Mixed convection boundarylayer flow from a horizontal circular cylinder in micropolar fluids: Case of constant wall temperature. International Journal of Numerical Methods for Heat \& Fluid Flow 13(1): 86-109.

Nield, D.A. \& Kuznetsov, A.V. 2009. The Cheng-Minkowycz problem for natural convective boundary-layer flow in a porous medium saturated by a nanofluid. International Journal of Heat and Mass Transfer 52(25-26): 5792-5795.

Noghrehabadi, A., Pourrajab, R. \& Ghalambaz, M. 2012. Effect of partial slip boundary condition on the flow and heat transfer of nanofluids past stretching sheet prescribed constant wall temperature. International Journal of Thermal Sciences 54: 253-261.

Qasim, M., Khan, I. \& Shafie, S. 2013. Heat transfer and mass diffusion in nanofluids over a moving permeable convective surface. Mathematical Problems in Engineering 2013: Article ID. 254973.
Rashad, A.M., Chamkha, A.J. \& Modather, M. 2013. Mixed convection boundary-layer flow past a horizontal circular cylinder embedded in a porous medium filled with a nanofluid under convective boundary condition. Computers and Fluids 86: 380-388.

Rawi, N.A., Ilias, M.R., Isa, Z.M. \& Shafie, S. 2016. G-jitter induced mixed convection flow and heat transfer of micropolar nanofluids flow over an inclined stretching sheet AIP Conference Proceedings 1775(1): 030020.

Sarkar, S., Ganguly, S., Biswas, G. \& Saha, P. 2016. Effect of cylinder rotation during mixed convective flow of nanofluids past a circular cylinder. Computers and Fluids 127: 47-64.

Soundalgekar, V.M. 1972. Viscous dissipation effects on unsteady suction porous flow past an infinite, with constant. Int.J.Heat Mass Transfer 15: 1253-1261.

Tiwari, R.J. \& Das, M.K. 2007. Heat transfer augmentation in a two-sided lid-driven differentially heated square cavity utilizing nanofluids. International Journal of Heat and Mass Transfer 50(9-10): 2002-2018.

Zaib, A., Bhattacharyya, K. \& Shafie, S. 2015. Unsteady boundary layer flow and heat transfer over an exponentially shrinking sheet with suction in a copper-water nanofluid. Journal of Central South University 22(12): 4856-4863.

Zokri, S.M., Arifin, N.S., Salleh, M.Z., Kasim, A.R.M. Mohammad, F. \& Yusoff, W.N.S.W. 2017a. MHD Jeffrey nanofluid past a stretching sheet with viscous dissipation effect MHD Jeffrey nanofluid past a stretching sheet with viscous dissipation effect. Journal of Physics: Conference Series Paper 890: 1-6.

Zokri, S.M., Arifin, N.S., Mohamed, M.K.A., Salleh, M.Z. Kasim, A.R.M. \& Mohammad, N.F. 2017b. Numerical solution on mixed convection boundary layer flow past a horizontal circular cylinder in a jeffrey fluid with constant heat flux. AIP Conference Proceedings 1870(1): 040034.

Rahimah Mahat

Universiti Kuala Lumpur Malaysian

Institute of Industrial Technology

Persiaran Sinaran Ilmu

81750 Johor Bahru, Johor Darul Takzim

Malaysia

Rahimah Mahat, Noraihan Afiqah Rawi \& Sharidan Shafie*

Universiti Teknologi Malaysia

81310 Johor Bahru, Johor Darul Takzim

Malaysia

Abdul Rahman Mohd Kasim

Universiti Malaysia Pahang

Lebuhraya Tun Razak

26300 Gambang, Kuantan, Pahang Darul Makmur

Malaysia

*Corresponding author; email: sharidan@utm.my

Received: 26 September 2017

Accepted: 19 February 2018 